inhibitors in the collecting tubes, minor aggregation of platelets and consequent release of $\mathrm{TxB}_{2}$ during sampling is largely unavoidable. The raised plasma $\mathrm{TxB}_{2}$ concentrations might therefore in part reflect the increased capacity of the platelets to produce $\mathrm{TxB}_{2}$ during aggregation. That there is an increased generation of $\mathrm{TxB}_{2}$ in response to thrombin-induced platelet aggregation during pregnancy and puerperium is, however, indisputable. What causes this stimulation remains to be investigated.

This study was supported by grants from the Medical Research Council, Academy of Finland.

${ }^{1}$ Lewis PJ, Boylan P, Friedman LA, Hensby CN, Downing I. Prostacyclin in pregnancy. Br Med $\mathcal{F} 1980 ; 280 ; 1581-2$.

${ }^{2}$ Hamberg M, Svensson J, Samuelsson B. Thromboxanes. A new group of biologically active compounds derived from prostaglandin endoperoxides. Proc Natl Acad Sci 1975;72;2994-8.

${ }^{3}$ Caillouette JC. Prevention and early diagnosis of thromboembolic disease in obstetrics and gynecology. Clin Obstet Gynecol 1968;11;233-56.

${ }^{4}$ Beller FK. Thromboembolic disease in pregnancy. Clin Obstet Gynecol $1968 ; 11: 290-311$.

${ }^{5}$ Mitchell MD, Bibby JG, Hicks BR, Redman CWG, Anderson ABM, Turnbull AC. Thromboxane $B_{2}$ and human parturition: concentrations in the plasma and production in vitro. 7 Endocrinol 1978;78:435-41.

(Accepted 9 October 1980)

Departments of Obstetrics and Gynaecology and Clinical Chemistry, University of Oulu, Oulu, Finland

O YLIKORKALA, MD, senior researcher

$L$ VIINIKKA, MD, research scientist

\section{Acute folate deficiency during peritoneal dialysis}

Acute megaloblastic arrest of haemopoeisis in patients receiving parenteral nutrition after extensive surgery or trauma is well recognised. ${ }^{1}$ Rapidly developing life-threatening pancytopenia in pregnancy complicated by severe bacterial infection has also been described. ${ }^{2}$ Both have been attributed to acute folate deficiency. Less well recognised is the occurrence of acute folate deficiency in other conditions needing critical care. ${ }^{3}$ We report a case of severe rapid-onset pancytopenia resulting from acute folate depletion during the course of peritoneal dialysis.

\section{Case report}

A 64-year-old man was referred with acute tubular necrosis that developed after intravenous antihypertensive treatment. The results of initial haematological investigations (figure) were: haemoglobin concentration $13.7 \mathrm{~g} / \mathrm{dl}$, mean corpuscular volume $84 \mathrm{fl}$, white cell count $10 \cdot 2 \times 10^{9} / 1\left(10200 / \mathrm{mm}^{3}\right)$ with a normal differential count. The reticulocyte count was $<1 \%$. His platelet count was $280 \times 10^{9} / 1\left(280000 / \mathrm{mm}^{3}\right)$, prothrombin time $12 \mathrm{~s}$ (control $12 \mathrm{~s}$ ), partial thromboplastin time $40 \mathrm{~s}$, (control $38 \mathrm{~s}$ ), fibrin degredation products. $<10 \mathrm{mg} / \mathrm{l}$. His urine to serum osmolarity ratio was $<1 \cdot 0$, and urinary sodium concentration was $40 \mathrm{mmol}(\mathrm{mEq}) / \mathrm{l}$. Sediment microscopy showed red and white cells but no casts. Blood and urine cultures were sterile. Renal tomography showed large swollen kidneys.

$\mathrm{He}$ required three courses of peritoneal dialysis, each consisting of 40 exchanges, during the oliguric phase of 16 days. During peritoneal dialysis he suddenly had generalised bleeding and blood staining of the dialysate. Repeat investigations showed that his white cell count had fallen to $1 \cdot 2 \times 10^{9} / 1$ $\left(1200 / \mathrm{mm}^{3}\right)$ and the platelets to $12 \times 10^{9} / 1\left(12000 / \mathrm{mm}^{3}\right)$. The haemoglobin was $8.4 \mathrm{~g} / \mathrm{dl}$ mean corpuscular volume $87 \mathrm{fl}$, mean corpuscular haemoglobin concentration $32.4 \mathrm{~g} / \mathrm{dl}$, and mean corpuscular haemoglobin $28.0 \mathrm{pg}$. The reticulocyte count was $<1 \%$. Occasional macrocytes and hypersegmentation of polymorphs were noted on the peripheral blood film. Bone marrow aspirate showed severe megaloblastic change particularly affecting the white cell series. Megakaryocytes were present and the myeloid-erythroid ratio was $11: 1$. Folate concentrations measured at the time of the pancytopenia later showed a much diminished serum folate concentration of 0.5 $\mu \mathrm{g} / 1$ (normal 2.7-20 $\mu \mathrm{g} / \mathrm{l}$ ) and a normal red cell folate concentration of $224 \mu \mathrm{g} / \mathrm{l}$ (normal 150$1000 \mu \mathrm{g} / \mathrm{l}$ ). His vitamin $B_{12}$ concentration was $230 \mathrm{ng} / 1$ (normal 150-1000 $\mathrm{ng} / \mathbf{l}$.

Intravenous folate $10 \mathrm{mg} / \mathrm{day}$ was given and his platelet and white cell counts returned to normal levels within four to five days. Associated with this was a mild reticulocyte response of $3 \%$. He was given a further two-week course of folate $5 \mathrm{mg}$ /day by mouth. He made a satisfactory recovery and when discharged his full blood count and peripheral film were normal and his renal function mildly impaired. His renal function has since improved further and there has been no recurrence of any haematological abnormalities.

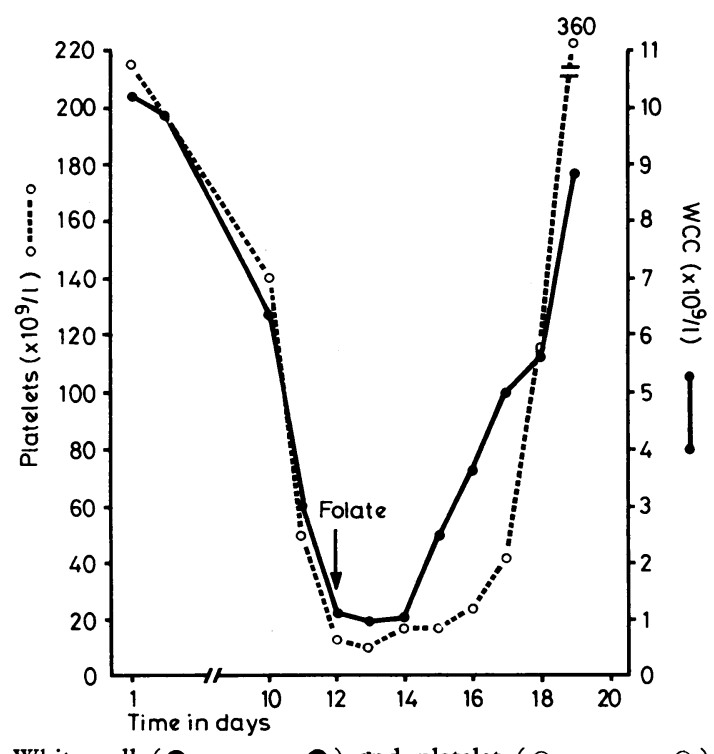

White cell ( -0$)$ and platelet $(0---0)$ oped acute folate deficiency during peritoneal dialysis.

\section{Comment}

Apart from ethanol, which may interfere with the intermediary metabolism of folate, other factors may contribute to the development of acute folate deficiency in severely ill patients. ${ }^{1}$ In normal subjects taking a diet deficient in folate it may be 18 to 20 weeks before megaloblastic changes appear within the bone marrow although serum folate concentrations may become subnormal within two to three weeks. Therefore anorexia probably had only a minor role in our patient. Systemic infection appreciably interferes with jejunal absorption of folate and may also adversely affect folate metabolism. ${ }^{4}$ Our patient showed no evidence of local or systemic infection at any time. Folate is loosely bound to protein in serum and is thus lost from the body during haemodialysis ${ }^{5}$-about $50 \mu \mathrm{g}$ in each exchange. Similarly, serum folate is lost during peritoneal dialysis, although how much is lost is uncertain. In the absence of any of the recognised precipitating factors we are tempted to speculate that the recurrent peritoneal dialysis, by rapidly removing folate, played a predominant part in causing our patient's pancytopenia.

The diagnosis depends on being aware of the condition and of the implication of a rapidly developing pancytopenia in a severely ill patient. It is confirmed by examination of a bone marrow aspirate. Because of the delay in recovery of white cell and platelet counts, even after early diagnosis and treatment, we suggest that prophylactic folic acid supplements should be given to patients having repeated peritoneal dialysis. At a minimum white cell and platelet counts should be closely monitored.

${ }^{1}$ Heatley RV, Wardrop CAJ, Tennant GB, Hughes LE. Acute folate deficiency in surgical patients on amino acid/ethanol intravenous feeding. Lancet 1975 ;ii: $640-2$.

2 Channarin I, Davey DA. Acute megaloblastic arrest of haemopoeisis in pregnancy. Br $\mathcal{F}$ Haematol 1964;10:314-9.

${ }^{3}$ Green PJ. Folate deficiency and intravenous nutrition. Lancet 1977; : 814.

${ }^{4}$ Cook JC, Morgan JO, Hoffbrand AV. Impairment of folate absorption by systemic bacterial infection. Lancet 1974 ;ii:1416-7.

${ }^{5}$ Hampers CL, Streiff R, Nathan DG, Snyden D, Merrill JP. Megaloblastic haematopoeisis in anaemia and in patients on long term haemodialysis. $N$ Engl f Med 1967;276:551-4.

(Accepted 7 October 1980)

Department of Medicine and Nephrology, Meath Hospital, Dublin 8 A J S WATSON, MB, MRCPI, registrar in nephrology E LAWLOR, MB, MRCPATH, registrar in haematology J A B KEOGH, MD, FRCPI, consultant nephrologist 